DEFARTMENT OF COMMERCE BUREAU OF STANDARDS

WASHITGTON

$\mathrm{V}-\mathrm{I}$
Letter

Circular

LC 301

April 9, 1931.

\title{
TRAFFIC PAINT
}

This Bureau has not made a very extensive investigation of traffic paint. However at the request of the Traffic Department of the District of Columbia an investigation was made Which was confined to white traffic marking paint for use on biturninous or cement-concrete roadways. As a result of this investigation there was prepared for the District of Columbia in January 1928 a tentative specification for white traffic paint having a pigment containing at least 85 per cent of lithopone. Later experiments indicated that addition of zinc oxide to the pigment improved the paint, and the following tentative specification for Traffic White Paint represents our latest recommendations.

\section{Tentative Specification for Traffic White Paint}

(Somipaste and Ready-Mixed)

I. GENERAI

This paint is intended for outdoor use on bituminous or cement-concrete roadways.

II. CLASSES

Traffic white paint shall be of the following classes as spccificd: Scmipastc or ready-mixcd paint. 
$\because 1$
$\cdots \quad \cdots \quad$
$\therefore \quad \cdots$ $\therefore \quad \therefore \quad \therefore \quad \therefore$ $\therefore \therefore, \therefore$ $\therefore \therefore \ldots$ $\therefore \quad, \ldots$ 
LC 301, Traffic Paint

2.

III. MATERIAL

See Section $V$.

IV. GENERAL REQUIREMENTS

See Section $V$.

V. DETAII REQUIREMENTS

1. Pigment.- The pigment shall be composed of:

Maximum Minimum

Per Cent Per Cent

Iithopone . . . . . . . 65

55

Zinc oxide ...........

35

20

Paint pigments other than lithopone

and zinc oxide.........

15

The lithopone used shall contain not less than 28 per cent of zinc sulphide and shall not darken on exposure.

2. Iiquid:- The liquid in both the semipaste and the rcady-mixed paint shall consist of a pale-colored varnish together with turpentine or volatile mincral spirits or a mixture thereof. The vehicle in the scripaste shall contain not less than 65 per cent of non-volatile matter, which shall dry to a tough, clastic, and durable film. The vehicle in the ready-mixed paint shall contain not less than 45 per cent of non-volatile matter which shall also dry to a tough, elastic, and durable film. This shall be determined by the method given in Bureau of Standards Circular No. 147, page 5, paragraph (k), "Iature of Nonvolatile Vehicle". 

3. Semipaste.- Semipacte shall be made by thoroughly grinding the pigment with the liquid. The semipasto as recoived and threc months thercafter shall be of a smooth paste consistency that can be thinned with the usual paint liquids. The paste shall consist of:

Maximum Minimum Per Cent Per Cent

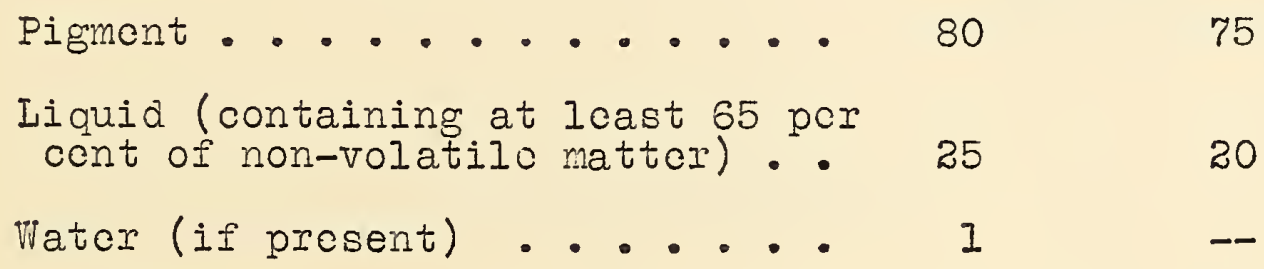

4. Ready-Mixed Paint.- Ready-mixed paint, as received, shall be suitable for use with the usual paint brush or a paint machine. It shall be well ground, shall not "liver", settle badly, cake, or thicken in the container within three months of date of delivery. It shall flow evenly and smoothly, and shall cover solidly in one coat on asphalt. It shall not cause the asphalt to "bleed" either during application or while it is drying. A single coat shall sot within one-half hour (so that there shall bo no pick-up under traffic) and thoroughly dry within one hour (free from tackiness) to an clastic, opaque, acherent finish. It shall give a brilliantly whito finish frec from laps or brushmarks. It shall not turn gray in sunlight or show apprcciablc discoloration with age. The color, hiding power and finish, when epecificd, shall bo 

equal to those of a sample mutually agreed upon. The paint shall pass the toughness and elasticity test ae given in Federal Specification No. 21b (Bureau of Standards Circular No. 111, 3d Ed., page 6) except that the addition of kauri solution shall be omitted.

The paint shall consist of:

Moximum Minimum Per Cent Per Cent

Pigment . . . . . . . . . . - 65

Iiquid (containing not less than 45 per cent of non-volatile matter). 35

Water (if present)

VI. METEODS OF TEST

Methode of tests shall be those used at the U. S. Bureau of Standards.

We are not prepared to recomend this as a standard specification for traffic paint, thougin it appears to be giving good service.

The methods of test referred to in Section VI of the above specification are contained in Fedcral Specification No. 2Ib which is now obtainable as Burcau of Standards CircuIar No. 1ll, $3 a$ Ed., for 5 cents (stamps not accopted) from the Superintendont of Documente, Government Printing Office, 

LC 301, Traffic Paint

Washington, D. C. Federal Specification No. 2 Ib will be printed later by the Federal Specisications Board as part of the Federal Standard Stock Catalogue under the specification Symbol TT-P-4I, and Bureau of Standards Circular 147, Federal Specification lio. 67 will be printed later as part of the Federal Standard. Stock Catalogue under the specification symiol TT-P-46. 


